\title{
DETERMINANTS OF ABANDONED \\ HOUSING PROJECTS IN MALAYSIA
}

\author{
Dzuljastri Abdul-Razak ${ }^{1}$
}

* Affiliation:

'Department of Finance Kulliyyah of Economics and Management Sciences International Islamic University Malaysia

\begin{abstract}
The issues of abandoned housing projects are not new in Malaysia. Without proper measures to tackle, they will continue to haunt home buyers. This study examines responses of 328 customersobtained by means of self-administered questionnaires. Four variables namely lack of justice and equity, methods of computing and pricing, nature of contract and lack of legal and governance were used as variables. The results indicated that all the hypothesized relationships are supported. Of these, the nature of contract was found to be the main cause of the problem. The results contributes to the scanty empirical research in this area. It also benefits managers of Islamic banks to address issues that are affectingabandoned housing projects in Malaysia.
\end{abstract}

Keywords: Abandoned housing projects, Consumers, Islamic home financing, Home buyers, Malaysia

\section{INTRODUCTION}

The Malaysia housing sector has achieved tremendous strides over the years by making housing affordable to large part of the population. Nonetheless, this sector is still inundated with numerous challenges particularly the issues of abandoned housing project (AHP).

AHP is defined as the project which had stopped owing to financial problems, or the developer of that project has disappeared (Md-Dahlan, 2011). According to the Ministry of Urban Wellbeing, Housing and Local Government (MUHLG), a housing project is abandoned under the following circumstances.

Firstly, when the projects are not completed within or later than the delivery date stated in the first Sale and Purchase Agreement and no significant activity is noticed at the construction site for six (6) continuous months. Secondly, when petition for winding up has been registered in the High Court under Section 218 of the Companies Act 1965 or other related laws. Also, when a licensed housing developer is wound up and placed under Receivership, Liquidator or the Malaysia Department of Insolvency (MDI) the project is abandoned. Finally, a project is abandoned when a licensed housing developer notified 
in writing to the Housing Controller that they are unable to continue further with the development of the project; and lastly if certified by the MHLG under Section 11 (1) (c) of Housing Development (Control and Licensing) 1966 (Act 118) that the housing project is an abandoned project.

The Malaysian government is very concerned on the plight faced by home buyers with regards to Abandoned Housing Project (AHP). Furthermore, there were 68 private housing projects in Peninsular Malaysia listed as abandoned projects during 2014. This involves 24,726 housing units and 17,468 buyers (MUHLG, 2014). Theissue of abandoned housing project is indeed burdensome not only to the home buyers but also to the government and society. For instance, home buyers are required to pay back the financing amount even though the house is not completed.

Despite the problems of the alarming rate of abandoned housing projects, studies that investigate the causes and customers perception of home buyers are scant. Therefore, the aim of this study is to examinethe factors that determine abandoned housing projects in the context of buyers of Islamic home financing in Malaysia.

\section{LITERATURE REVIEW AND HYPOTHESES Related literature on Abandoned Housing Project}

By definition, abandoned housing projects are referred to the construction activities on site that have stopped for six months or more, after the expiry of the sale and purchase agreement executed by the developer (Md-Dahlan, 2008). On the same note, it also refers to the developer who has been placed under the control of the official receiver and the housing controller is of the opinion that such a developer cannot duly proceed with the execution of its obligations as a developer.

The problem of abandoned housing projects is one of the predicaments faced by the Malaysian government and home buyers because the housing industry is a significant sector in the economy. According to statistics published by central bank of Malaysia, $31 \%$ of the total financing is used to purchase residential and non residential (BNM, 2014).In fact, the problem of abandoned housing projects has brought negative implications to home buyers, government and society. Under theBai Bithaman Ajil (BBA) mode of financing, home buyers are required to pay back the full financing amount although there is no guarantee that the house purchase can be completed. This, in turn creates a dilemma to buyers because the househave not been completed yet. This situation indicateslack of justice and equity in present mode of home financing

In Malaysia, the issue of abandoned housing projects can be traced back in 1983 since the formation of Bank Islam Malaysia Berhad (BIMB).and recently the issue is still occurring, making it as one of the main concern of the Malaysian government (Zairulet al., 2008). The abandoned housing projects can hamper the growth of houses needed by the nation. In fact, consumers are severely affected by the problem because they are not aware of the technical knowledge of the products such as various features andmethods of computing and pricing of the home financing package.Hence forth, the Malaysian government plays a critical role 
in ensuring that the issue of abandoned housing projects need to be addressed effectively. The problem of abandoned housing projects is unpredictable and it can occur at any stage of housing development. When it happens, house buyers always become the victims. Hence, it is pertinent to obtain customers' opinion on this issues being investigated and together with other inputs would enable the Malaysian government to formulate policies to address the situation. In the current study, customers of Islamic banks and home buyers are used interchangeably. Home buyers' perception of four the factors were obtained from previous studies namely lack of justice and equityand method of computing and pricing, (Abdul-Razak, D, 2011); nature of contract (Rosly, 2005) and lack of legal and governance (Khalid, 2010).

\section{Justice and equity}

As argued earlier, lack of justice and equity in the existing home ownership between the customer, the Islamic bank and the developer has contributed to the problem of abandoned housing projects. The current study reviews five related works. A study by Tan (2011) argues that lack of justice and equity is a contributing factor leading to the problem of abandoned housing projects. This is because home buyers are exposed to the risk of uncompleted houses as the bank does not take ownership of the property. Furthermore, developers have usedsubstandard materials resulting in uneven flooring and poor quality ofconcrete. Meanwhile, Razali (2011) views that sell and build system is considered as one of the reasons for abandoned housing projects in Malaysia. This situation occurs because developers are paid in advance before the completion of the housesbut not able to fulfil the progressive stages in the contract.Unlike Tan (2011) and Razali (2011), a study by Md-Dahlan and Syed-AbdulKader-Aljunid (2011) has assessed the Bai BithamanAjil (BBA) and its link to the abandoned housing projects. The practice of BBA is based on debt financing. In the case of abandoned housing projects, debtors of the BBA are required to maintain a series of monthlypayments although the housing projects are abandoned. Some may even have to rent another house to live pending the completion of the house under construction. This is not fair as it will incur additional cost to the home buyers. Yap et al. (2010) also argue that developers normally take less measure to prevent the abandoned housing projects. Therefore, home buyers face with the denial of potential value appreciation and rental collection. High profit rate in the case of economic crisis also contributes to the dilemma of abandoned housing projects as customers are required to service the profit pending completion of the house. Khalid's (2010) alsoexamines the development of abandoned housing in Malaysia. His study explains that there is unfair conditions designed by financial institutions in approving the financing that can be one of the reason for the problem. Without sufficient funds, the housing projects will meet with failures. Given these studies lack of justice and equity can be a substantial barrier that leads to problem of abandoned housing projects. On the basis of these arguments, the following hypothesis is proposed:

$\mathrm{H}_{1}$ : Lack of justice and equity will aggravate the problem of abandoned housing projects. 


\section{Methods of computing and pricing}

In order to investigate the effect of methods of computing and pricing, we examined five studies that are related to the abandoned housing projects (Siddiqi, 1985; Rosly, 1999; Mydin-Meera and Abdul-Razak, 2005; Mohammed et al., 2008; Abdul-Razak and Md-Taib, 2011). A study made by Siddiqi (1985) indicated the over-reliance of Islamic banks on the use of debt as a mode of financingto customers which is burdensome. It is widely known that the Islamic banks are using interest rates as its benchmarks to profit rates in home financing. As debt financing in BBA is based on fixed profit rate, it is not flexible and the customers have to pay the entire selling price in case of abandoned house as the property has been sold earlier. In response to this concern, some authors have suggested the use of equity financing as an alternative (e.g. Mydin-Meera and Abdul-Razak, 2005; Mohammed et al., 2008).

In equity financing, the Islamic bank and the customer are the joint owners of the house and share risk jointly until the house is completed. In terms of pricing, the benchmark is based on the actual value of property which differ from one location with another. Unlike, fixed profit, the use of rental rate in equity financing is flexible and can be varied according to changes in the economy. In the case of abandoned house, the customer is not saddled with the entire selling price but share the risk with the bank.There exit risk sharing element in equity financing which can mitigate the issue of abandoned housing projects because of the controls elements found in the equity financing. Like Mydin-Meera and Abdul-Razak (2005) and Mohammed et al. (2008), Abdul-Razak and Md-Taib (2011) are also in agreement.

Explained in more detail, Abdul-Razak and Md-Taib (2011) argues that profit rate currentlyused inBai BithamanAjil (BBA) has a negative implication to consumers compared to rentalrate used in Musharakah Mutanaqisah (MM) home financing. The current practice of BBA home financing is tied up to the pricing mechanism used in the conventional home loans, that is, interest, Abdul-Razak and Md-Taib (2011). Abdul Razak (2011) further argues that consumers pay higher for BBAfinancing compared to MMhome financing because in BBA, the profit is capitalised upfront.

Based on this argument, it is expected that methods of computing and pricing can be a factor that influence abandoned housing projects. Therefore the following hypothesis is develop:

$\mathrm{H}_{2}$ : Methods of computing and pricing will affect the problem of abandoned housing projects.

\section{Nature of contract}

In this study, the term nature of contract is best described asthe Shariah principles used to govern consumers' home financing. Five studies are reviewed (e.g. Bendjilali and Khan, 1995; Rosly, 2005; Ahmad and Hassan, 2009; Hasan, 2011; AbdulRazak and Md-Taib, 2011; Ariset al., 2012). According the Bendjilali and Khan (1995), the concept of sell and buy back found in Bai BithamanAjil (BBA) has been burdensome to customers when abandoned housing projects occurred as the property has already been sold upfront to the customer. This is supportedby an earlier study made by Siddiqi (1985) which state the banks' rampant use of debt financing has cause a burden to the customer. This is also not in line with the principles of Maqasid al Shariah (Al Ghazali, 1937) which promote the social wellbeing of society. 
On the other hand, the equity principle in MusharakahMutanaqisah (MM).home financing is more appropriate for customers in home financing under construction. This is because, unlike BBA, the property is not sold upfront to the customer dissolving the bank of any risk that may occur. Under MM, the forward lease contract (Al Ijarah al MawsufahFi al Dhimma) is used whereby the bank will still bear the responsibility of the house until it is completed. Furthermore, there exists a joint venture between the bank and customer, which ensures the houses under construction are delivered on time. Three studies by Aris et al. (2012), Hasan (2011) and Rosly (2005) are in agreement that in BBA there is no risk sharing, liability and effort (Iwad) which is an important legal maxim to ensure counter values exist to make the sale transaction valid (Rosly, 2005)

On the other hand, according to Ahmad and Hassan (2009) equityhome financing is a better alternative compared todebt based home financing because in MM, bankis a partner in owning the house with the customer. Hence by taking joint ownership, will eliminate, the issue of Bai Inah or legal trick that exist in BBA that contributed to the problem of abandoned housing projects in Malaysia,Hence based on these issues, the following hypothesis is put forward

$\mathrm{H}_{3}$ : Nature of contract will affect the problem of abandoned housing projects.

\section{Legal and governance}

Prior studies have documented that lack of legal and governance for housing project is deliberated as one of the reasons that make the case for abandoned housing projects. (e.g. Khalid, 2010; Tan, 2011; Hoe, 2013).A study by Khalid (2010) on abandoned housing development in Malaysia revealed that the bank's stringent condition on funding provided to the developer has been instrumental in causing the problem of abandoned housing projects. On the other hand, a study by Tan (2011) examines the sustainability and housing provision in Malaysia. He explained that some of the potential causes for the problem of housing projects are delay in the process for approving of land development, subdivision and issuance of titles. In addition the ambiguous relationship between federal government, state government and local authority in terms of housing projects are also classified as contributing factors. Similar to Khalid (2010) and Tan (2011), Hoe (2013) indicated in their studies that legal and governance issues arethe possible reasons that causes abandoned projects from recurring. It is also reported that absence of special tribunal for home buyers, lack of home indemnity insurance and land policy, to name a few, have contributed to the problem of abandoned housing projects.. On the basis of this argument, the following hypothesis is proposed:

$\mathrm{H}_{4}$ : Lack of legal and governance will affect the problem of abandoned housing projects.

\section{METHOD}

Samples

Respondents of the current study are home buyers that utilize Islamic home financing products in Malaysia. This study uses judgemental sampling distributed to 500 respondents in all states in West Malaysia. It is conducted by means of self-administered questionnaires 
from February and March, 2015. As far as judgemental sampling is concerned, two criteria are established. First, respondents should be the existing customers of Islamic banks who have experiences in Islamic banking transactions. Second, respondents should be the existing home buyers who are facing the problem of abandoned housing projects in Malaysia. Of the 500 questionnaires obtained, a total of 328 questionnaires are usable and retain for the further analysis of data.

\section{RESULT AND DISCUSSION}

Profile of respondents

Table 1 described summarized the descriptive statistics of the respondents.

Table 1: Demographic results

\begin{tabular}{llcc}
\hline Profile & Description & Respondents & Percentage \\
\hline Gender & Male & 176 & 53.7 \\
Age & Female & 152 & 46.3 \\
& $<30$ & 77 & 23.5 \\
\multirow{4}{*}{ Religion } & $31-40$ & 78 & 23.8 \\
& $>40$ & 173 & 52.7 \\
& Islam & 272 & 82.9 \\
& Buddha & 30 & 9.1 \\
& Hindu & 16 & 4.9 \\
Monthly income & Christian & 7 & 2.1 \\
& Others & 3 & .9 \\
& $<3,000$ & 91 & 27.7 \\
& $3,001-5,000$ & 123 & 37.5 \\
& $5,001-10,000$ & 73 & 22.3 \\
& $10,001-20,000$ & 29 & 8.8 \\
& $>20,000$ & 12 & 3.7 \\
\hline
\end{tabular}

A total of 13 questionnaire items are structured specifically to the current study. All items used are developed by considering relevant literatures that capture "lack of justice and equity", "method of computing and pricing", "nature of contract"and "lack of legal and governance" and "abandoned housing projects", In terms of justice and equity, four studies by Khalid (2010), Dahlan and Aljunid (2011), Razali (2011) and Tan (2011) are referred to. As for legal and governance, three works by Khalid (2010), Tan (2011) and Hoe (2003) are reviewed. Concerned with methods of computing and pricing, Siddiqi (1985), Rosly (1999) and Mydin-Meera and Abdul-Razak (2005) were reviewed. With respect to the "nature of contract", the current study refers and reviews three works, namely, Bendjilali and Khan (1995), Rosly (2005) and Ahmad and Hassan (2009). Explained in more detail, three items each are developed to capture the variables for "method of computing and pricing", "lack of justice and equity" and "lack of legal and governance". Two items each for "abandoned housing projects" and "nature of contract". In the questionnaire, home buyers are required to rate their level of agreement with items tested using a five-likert scale ranging from "strongly disagree" (1) to "strongly agree" (5). 
The current study examines the data using partial least squares (PLS). The PLS considers two approaches namely measurement model and structural equation modelling. The details are provided:

\section{Measurement model}

In this section, measurement model includes several tests including convergent validity, discriminant validity and reliability. Table 2 presents results pertinent to reliability and convergent validity. Concerned with average variance extracted (AVE), all values obtained for the constructs are higher than the threshold value of 0.5 . On the same note, the values for composite reliability for the constructs tested are also satisfactory, meeting the threshold value of 0.7. Besides AVE and composite reliability, Table 3 provides further indication whether the constructs tested are valid or not based on factor loadings. Evidently, all factor loadings for the constructs' indicators are greater than the threshold value of 0.7 . Taken as a set, all constructs tested have sufficient convergent validity. On the other hand, the values for Cronbach's alpha for all constructs are higher than the recommended value of 0.6 , indicating that the indicators used to capture the constructs are highly consistent and related from one to another. Consequently, all indicators are retained.

Table 2: Reliability and convergent validity

\begin{tabular}{lllll}
\hline Construct & AVE & Composite Reliability & R Square & Cronbachs Alpha \\
\hline AHP & 0.74 & 0.85 & 0.62 & 0.65 \\
JE & 0.64 & 0.84 & 0.00 & 0.72 \\
LG & 0.58 & 0.81 & 0.00 & 0.65 \\
MCP & 0.59 & 0.81 & 0.00 & 0.65 \\
NOC & 0.72 & 0.84 & 0.00 & 0.61 \\
\hline
\end{tabular}

Notes: $A H P=$ Abandoned housing projects, $J E=J u s t i c e$ and equity, $L G=$ Legal and governance, $M C P=$ Methods of computing and pricing and NOC=Nature of contract

Table 3 also presents cross-loadings that are important to prove whether the indicators belong to the construct as what they are supposed to measure or otherwise. Evidently, all of the items tested exhibit greater loadings on their constructs and no items are loaded higher on constructs they are not supposed to measure.

Table 3: Factor loadings and cross-loadings

\begin{tabular}{llllll}
\hline Dimension & MCP & JE & LG & AHP & NOC \\
\hline MCP1 & $\mathbf{0 . 7 4}$ & 0.52 & 0.33 & 0.40 & 0.32 \\
MCP2 & $\mathbf{0 . 8 2}$ & 0.49 & 0.35 & 0.46 & 0.27 \\
MCP3 & $\mathbf{0 . 7 4}$ & 0.47 & 0.38 & 0.39 & 0.28 \\
JE1 & 0.64 & $\mathbf{0 . 7 5}$ & 0.54 & 0.54 & 0.36 \\
JE2 & 0.44 & $\mathbf{0 . 8 4}$ & 0.51 & 0.57 & 0.54 \\
JE3 & 0.46 & $\mathbf{0 . 8 0}$ & 0.50 & 0.46 & 0.45 \\
LG1 & 0.37 & 0.56 & $\mathbf{0 . 7 3}$ & 0.47 & 0.49 \\
LG2 & 0.28 & 0.42 & $\mathbf{0 . 7 3}$ & 0.42 & 0.39
\end{tabular}




\begin{tabular}{llllll}
\hline Dimension & MCP & JE & LG & AHP & NOC \\
\hline LG3 & 0.39 & 0.50 & $\mathbf{0 . 8 3}$ & 0.61 & 0.42 \\
AHP1 & 0.49 & 0.56 & 0.61 & $\mathbf{0 . 8 6}$ & 0.49 \\
AHP2 & 0.45 & 0.58 & 0.54 & $\mathbf{0 . 8 7}$ & 0.64 \\
NOC1 & 0.33 & 0.50 & 0.50 & 0.61 & $\mathbf{0 . 8 8}$ \\
NOC2 & 0.31 & 0.47 & 0.46 & 0.50 & $\mathbf{0 . 8 2}$ \\
\hline
\end{tabular}

Notes: $A H P=$ Abandoned housing projects, $J E=J u s t i c e$ and equity, $L G=L$ Legal and governance, $M C P=$ Methods of computing and pricing and NOC=Nature of contract

Table 4: Latent variable correlation matrix

\begin{tabular}{llllll}
\hline Construct & AHP & JE & LG & MCP & NOC \\
\hline AHP & $\mathbf{0 . 8 6}$ & & & & \\
JE & 0.66 & $\mathbf{0 . 8 0}$ & & & \\
LG & 0.67 & 0.65 & $\mathbf{0 . 7 6}$ & & \\
MCP & 0.54 & 0.64 & 0.46 & $\mathbf{0 . 7 7}$ & \\
NOC & 0.66 & 0.57 & 0.56 & 0.38 & $\mathbf{0 . 8 5}$ \\
\hline
\end{tabular}

Notes: $A H P=$ Abandoned housing projects, $J E=J u s t i c e$ and equity, $L G=$ Legal and governance, $M C P=$ Methods of computing and pricing and NOC=Nature of contract

Besides cross-loadings, this study reports latent variable correlation matrix to observe an evidence of discriminant validity among constructs tested. Table 4 depicts the correlations between the constructs with the square root of the AVE on the diagonal. All of the diagonal values exceed the recommended value of 0.707 (Lee and Kozar, 2008). The assessment of discriminant validity does not reveal any problems owing to the fact that the AVE for each construct is larger than the correlation of that construct with all other constructs in the model.

\section{Structural analysis}

Table 5 presents the results of model with direct effects. Explained in more detail, justice and equity are significantly related to the problem of abandoned housing projects $(t$-value $=2.20$, $p<0.05)$. Legal and governance are also found to be significantly associated with the problem of abandoned housing projects $(t$-value $=4.21, p<0.05)$. On the same note, methods of computing and pricing are significantly related to the problem of abandoned housing projects $(t$-value $=3.14$, $p<0.05)$. Furthermore, nature of contract is also found to be significant in the current context $(t$-value $=6.14, p<0.05)$. Of these factors, nature of contract is found to be the major contributing factor leading to the issue of abandoned housing projects among home buyers in Malaysia.As provided in Table 2, the $R^{2}$ is 0.62 indicating that 62 percent of the variation in the problem of abandoned housing projects could be explained by the four named factors. $R^{2}$ is a measure of the model's predictive accuracy and is calculated as the squared correlation between a specific endogenous construct's actual and predicted values (Hair et al., 2011). Following Hair et al. (2011), our $R^{2}$ is considered to be satisfactory meeting the minimum requirement of 0.20 in the area of consumer behaviour studies. Overall, all hypothesized hypotheses are supported. 
Table 5: Results of model with direct effects

\begin{tabular}{|l|l|l|l|l|}
\hline Pathway & Hypothesis & Path coefficient & $t$-value & Supported \\
\hline JE & H1 & 0.17 & $2.20^{*}$ & Yes \\
\hline LG & H2 & 0.29 & $4.21^{* *}$ & Yes \\
\hline MCP & H3 & 0.18 & $3.14^{* *}$ & Yes \\
\hline NOC & H4 & 0.33 & $6.14^{* *}$ & Yes \\
\hline
\end{tabular}

Notes: $A H P=$ Abandoned housing projects, $J E=$ Justice and equity, $L G=$ Legal and governance, $M C P=$ Methods of computing and pricing and NOC=Nature of contract

* Significant at the 5 percent, **Significant at the 1 percent

\section{IMPLICATIONS OF STUDY}

The current study has evaluated the effects of four factors namely, lack of justice and equity, methods and computing and pricing, nature of contract and lack of legal and governance with regards to abandoned housing project. The results indicated that all the hypothesized relationships in the model developed are confirmed. This explained the contributions that emerge from this study which can be categorized into three-folds. First, it expands the literature in the area of abandoned housing projects by highlighting the four factors are indeed within the context of Islamic home financing. Second, the current study discovers that "nature of contract" is considered to be the most important predictor of the problem of abandoned housing projects in Malaysia. Third, the use of PLS in this study has been fruitful. The current study expands the PLS literature to include abandoned housing projects. Chin's (2010) recommendation has been valid in understanding the constructs' items and the structural analysis. His study suggested that the "measurement model" and "structural equation modelling" in analysing data adopted in this study are relevant and robust.

As for the practical implications, the current study offers specific guidelines that provide further information for developers and the government to work on improving and strengthening housing project policy in Malaysia. On the developer's front, they should ensure that element of fairness and win-win situation should exist between the developer and the home buyer. This could be done by developing a framework that requires developerto operate businesses ethically and effectively.As for policy to be taken by government, this current study offers mechanism to further strengthen the modus operandi of the housing projects in Malaysia. In turn, the government should ensure that only a qualified developer should work on the housing projects in Malaysia. A monitoring program should be established for every housing project in order to ensure the issue of abandoned housing projects can be minimized.Needless to say, this work provides further debates with respect to the factors affecting the problem of abandoned housing projects in this country.

\section{CONCLUSION AND FUTURE RESEARCH AGENDA}

The main motivation for this study is to find out what factors that are affecting abandoned house in Malaysia. Out of the four factors evaluated, the nature of contract was found to be main factor that leads to abandoned house project. This indicates that the mode financinghas influenced on customers' perception of abandoned house. In the present practice, theBai BithamanAjil (BBA) 
mode has been widely use and is burdensome thecustomer for abandoned housing projects. Thisis becausebank does not take any risk in owing the house before selling it to the customers. Hence, the houses are sold first before they are build. On the other hand, the Musharakah Mutanaqisah is preferred because there is a joint ownership between the bank and customer. Hence there is partnership and joint responsibilities between the parties involved to ensure the completion of the house. The latter concept is also in line with the fulfilment of the purpose of Shariah (Maqasid Al Shariah) Al Ghazali (1937) which emphasizes on justice and fairness.

Several caveats are noted. Firstly, it coversselected geographical area in West Malaysia. Secondly, this study only employs a few measures in which other potential measures are not included in the current research's model. Taken as a set, these limitations drive a path for future research for new insights in this area. In order to address the first limitation, future studies should expand the locations to include East Malaysia. Concerned with second limitation, adding new measures (e.g. Shariah compliant issues, types of housing projects etc) will help to offer better prediction on the factors that causes abandoned housing projects faced by home buyers. Despite these flaws, this study is exploratory in nature that provides new thinking and direction of research in the area of abandoned housing projects in Malaysia.

\section{REFERENCES}

Ahmad, A. U. F. and Hassan, M. K. (2009). Legal and regulatory issues of Islamic finance in Australia. International Journal of Islamic and Middle Eastern Finance and Management, 2(4), 305-322.

Abdul-Razak, D. and Md-Taib, F. (2011). Consumers' perception on Islamic home financing: empirical evidences on Bai Bithaman Ajil (BBA) and diminishing partnership (DP) modes of financing in Malaysia. Journal of Islamic Marketing, 2(2), 165-176.

Abdul-Razak, D (2011). Diminishing Partnership As An Alternative Islamic Home Financing in Malaysia; Issues and Perceptions. Unpublished PhD dissertation, Universiti Sains Malaysia.

Aris, N. A., Othman, R., Azli, R. M., Arshad, R., Sahri, M. and Yaakub, A. R. (2012). Islamic house financing: comparison between bai' bithamin ajil (BBA) and musharakah mutanaqisah (MM). African Journal of Business Management, 6(1), 266-273.

Bendjilali, B. and T. Khan. (1995). Economics of Diminishing Musharakah. Islamic Research and Training Institute: Jeddah.

Chin, W.W. (2010). How to write up and report PLS analyses. In Vinzi, V.E., Chin, W.W.,

Hair, J.F. Jr, Ringle, C.M. and Sarstedt, M. (2011). PLS SEM: indeed a silver bullet. Journal of Marketing Theory and Practice, 19(2), 139-151.

Hasan, Z. (2011). Islamic house financing: current models and a proposal from social perspective. ISRA International Journal of Islamic Finance, 3(1), 7-24.

Hoe Y.E. (2003). Causes of abandoned construction projects in Malaysia. Unpublished Master Thesis, UniversitiTunku Abdul Rahman. 
Khalid M.S. (2010). Abandoned housing development: the Malaysian experience. Unpublished Ph.D Thesis, Heriot-Watt University, Edinburgh.

KPKT. (2015, September 11). Perangkaan 2014 (Tahunan). Retrieved from www.kpkt.gov. my:http:/www.kpkt.gov.my/resources/index/user_1/GALERI/PDF_PENERBITAN/ PERANGKAAN\%20TERPILIH/Buku_Perangkaan_KPKT_2014.pdf

Lee, Y. and Kozar, K.A. (2008). An empirical investigation of anti-spyware software adoption: a multitheoretical perspective. Information \& Management, 45(2), 109-119.

Mydin-Meera, A. K. and Abdul-Razak, D. (2005). Islamic home financing through musharakah mutanaqisah and al-bay' bithaman ajil contracts: a comparative analysis. Review of Islamic Economics, 9(2), 5-30.

Md-Dahlan, N.H. (2008). The need to define 'abandoned housing project' in peninsular Malaysia: an analysis. IIUM Law Journal, 16(1), 85-107.

Mohammed, M. O., Abdul-Razak, D. and Md-Taib, F. (2008). The performance measures of Islamic banking based on the maqasid framework. IIUM International Accounting Conference (INTAC IV), 1967.

Md-Dahlan, N. H. (2011). Legal Issues in the Rehabilitation of Abandoned Housing Projects of the Liquidated Housing-Developer-Companies in Peninsular Malaysia. European Journal of Social Sciences, 23(3). 392-409

Md-Dahlan, N.H. and Syed-Abdul-Kader-Aljunid, S.Z.(2011). Shariah and legal issues in house buying in Malaysia: the legality of bay' bithaman ajil (BBA) with special reference to abandoned housing projects. Pertanika Journal Social Science and Humanity, 19(2), 349-361.

Rosly, S.A. (1999). Al-bay bithaman ajil: impacts on Islamic banking performance. Thunderbird International Business Review, 41(4/5), 461-480.

Rosly, S. A. (2005). Islamic banking: doing things right and doing right things. Malaysian Journal of Economic Studies, 42(1-2), 31-40

Razali M.F.M. (2011). Build Then Sell (BTS): Delivering Dream Homes with More Protection to House Buyers. Housing News, 11.

Siddiqi, M.N. (1985), Parnership and Profit-Sharing in Islamic Law, Leicester, Islamic Foundation.

Tan T. (2011). Sustainability and housing provision in Malaysia. Journal of Strategic Innovation and Sustainability. 7(1), 62-71.

Yap E.H., Tan H. C. and Chia F.C. (2010). Causes of abandoned construction projects. available at http://www.researchgate.net/publication/263087852.

Zairul, M., Noor, M., \& Ibrahim, R. (2008). Abandoned Housing Projects in Malaysia: Proposal for Promoting the BTS (Build Then Sell) Concept for Malaysian Housing Development. In International Conference on Built Environment in Developing Countries, 2-4. 


\section{Appendix}

\begin{tabular}{ll}
\hline Dimension & Statement \\
\hline MCP1 & Using interest as a benchmark can lead customers to financial hardship \\
The bank that charges customers the entire selling price for abandoned houses \\
that do not exist can lead to financial burden to customers \\
MCP3 & $\begin{array}{l}\text { The bank that claims the disbursed amount including the entire selling price } \\
\text { for abandoned houses can create trauma to customers }\end{array}$ \\
JE1 & Using BBA does not uphold justice when the house is abandoned \\
JE2 & Using BBA does not benefit customers, but banks \\
JE3 & Lack of true spirit in Islam in Islamic home financing can be problematic \\
& when abandoned housing projects come into play \\
LG1 & Lack of track record of housing projects can lead to abandoned houses \\
LG2 & Lack of Islamic bank's intervention creates moral hazards to developers \\
LG3 & Lack of sufficient regulation leads to a problem of abandoned housing projects \\
AHP1 & I have faced the abandoned housing projects \\
AHP2 & I have seen that the abandoned housing projects is unfair to me \\
NOC1 & Lack of equity financing, is without doubt, problematic for Islamic home \\
& financing \\
NOC2 & Lack of partnership between the customer, the bank and the developer can \\
& lead to the problem of abandoned housing projects
\end{tabular}

